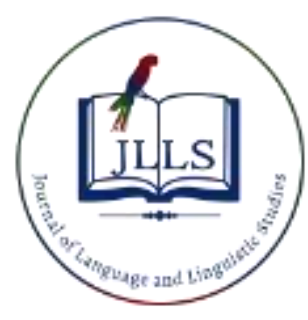

Available online at www.jlls.org

JOURNAL OF LANGUAGE

AND LINGUISTIC STUDIES

ISSN: $1305-578 \mathrm{X}$

Journal of Language and Linguistic Studies, 16(1), 474-488; 2020

\title{
Developing pragmatic comprehension and production: corpus-based teaching of formulaic sequences in an EFL setting
}

\author{
Nihan Yilmaz a 1 (iD), Didem Koban Koc ${ }^{\text {b }}$ (iD \\ ${ }^{a}$ Hacettepe University, Beytepe, Ankara, 06800, Turkey \\ ${ }^{b}$ Izmir Democracy University, Karabaglar, Izmir, 35140, Turkey
}

\begin{abstract}
APA Citation:
Yilmaz, N., \& Koban Koc, D. (2020). Developing pragmatic comprehension and production: Corpus-based teaching of formulaic sequences in an EFL setting. Journal of Language and Linguistic Studies, 16(1), 474-488. Doi: 10.17263/j1ls.712880

Submission Date: 20/12/2019

Acceptance Date: $08 / 01 / 2020$

Abstract

The present study aims to explore the effects of corpus-based teaching on English language learners' pragmatic comprehension and production of 19 formulaic sequences (FS), categorized under agreements, disagreements, self-clarifications and other-clarifications. The study had a quasi-experimental research design with a pre-test, immediate post-test and delayed post-test. A total of 35 students participated in the study and were divided into two groups. The experimental group $(\mathrm{N}=19)$ received corpus-based teaching whereas the control group $(\mathrm{N}=16)$ was exposed to traditional instruction and did not receive treatment at all. The results showed that there was a significant difference between the pre-test and immediate post-test and between immediate post-test and delayed post-test regarding the production of the targeted items for the experimental group. The findings indicate the effectiveness of corpus-based teaching in oral production, and the need for learners to engage with the real language data, corpus data, to improve their pragmatic competences.
\end{abstract}

(C) 2020 JLLS and the Authors - Published by JLLS.

Keywords: English as a foreign language; competence; comprehension; production; corpus, formulaic sequences.

\section{Introduction}

Learning a foreign language is almost always a challenge for learners of that language. Some of these challenges are internal, i.e learner related, like lack of enough learner autonomy (Wenden, 1998), motivation (Dörnyei, 1998; McDonough, 2007; Oxford \& Shearin, 1996), foreign language anxiety and (un) willingness to communicate (Horwitz, Tallon, \& Luo, 2009; MacIntyre, 2007) whereas some are external, like teacher behavior (Cheng \& Dörnyei, 2007; Stipek, 2002) and institutions (Richards, 2001).

\footnotetext{
${ }^{1}$ Corresponding author. Tel.: +0-232-260-1003

E-mail address: didem.koban@idu.edu.tr
} 
However, these two groups of factors affecting language learning are not independent from each other, on the contrary, they are inextricably intertwined (Robinson \& Ellis, 2008). This means that one external factor may increase or decrease the role of an internal factor in language learning.

Pragmatic competence and performance, which are the foci of the present study can be developed by factors such as course books, interactions with native speakers and practice with the target language used in daily life. However, some English as a Second language (ESL) course books lack the authentic, daily language used by native speakers of English (Pemberton, 2018) and therefore learners cannot learn the pragmatic or communicative strategies that they actually need. Access to the real language used by native speakers becomes even more difficult in countries such as Turkey where classroom is the only context where English is learned. In addition, there is teacher-fronted classroom discourse in many learning contexts in Turkey, where teachers tend to lecture and explain grammatical rules and expect learners to learn English this way. As a result, learners do not have a chance to interact with each other in the target language, which inhibits the development of pragmatic competence. These external factors that students have no or little control over affect their pragmatic competence. Students can understand what is being said in the target language but they cannot express themselves to the extent they need to, or they do not know how to respond to native speakers spontaneously, which show lack of pragmatic competence (Kasper \& Rose, 2002).

One way to improve the pragmatic competence and performance of learners is to teach them formulaic sequences (FSs). FSs are fixed combinations of words with functions and uses in speech production (Wood, 2006). FSs have an essential role in language learning as acknowledged by many scholars and their research (Bybee, 2006; Siyanova-Chanturia \& Martinez, 2015; Wray, 2013). However, there is lack of research on teaching FSs in classrooms in Turkey. FSs have a broad spectrum of functions, but for the present study, 19 FSs for agreement, disagreement, self-clarification and otherclarification are used because in order to express oneself in English, one needs to know how to react to a statement by agreeing or disagreeing, which is one of the most fundamental skills in learning a foreign language.

The primary aim of the present study is to see the effects of corpus-based teaching, a relatively new learning method whose roots are in the real language, on learners' pragmatic competences (both comprehension and production) in the short and long term. The reason for choosing corpus-based teaching is that corpora are composed of language, which is used by native speakers of that language and therefore are authentic not made up for a specific purpose and may provide learners the access to real language that they need to develop their pragmatic competences. The importance of this study lies in the fact that it is one of the few studies in Turkey that uses a corpus-based approach to teach FSs to enhance learners' pragmatic comprehension and production. The study aims to benefit teachers and learners by proposing a possible way to teach pragmatics and develop pragmatic competences of learners.

\subsection{Literature review}

\subsubsection{Corpus-based teaching}

Sinclair (1991) defined corpus as "a collection of naturally occurring language text, chosen to characterize a state or variety of a language" (p. 171), whereas Aarts (1991) defined it as "a collection of samples of running texts which may be in spoken, written or intermediate forms of any length" (p. 45). Although there are minor differences between the definitions of corpus, all share the main characteristics of a corpus: a set of naturally occurring language compiled and stored mostly, if not always, electronically. More simply, a corpus can be defined as a collection of texts (Kilgarriff, 2014), however, defining what corpus linguistics is not easy as it is not directly related to any specific aspect 
of language. Some scholars perceive it as a theory (Leech, 1991; Teubert, 2005; Tognini-Bonelli, 2001), whereas some others view it as a methodology (McEnery, Xiao, \& Tono, 2006). However, it may be best to merge the two views as corpus linguistics allows one to ask different kinds of questions and build new theories and to see how language variation is systematic through empirical research (Biber \& Reppen, 2015). The present study holds the corpus-based view of corpus linguistics, moving from the corpus to hypothesis verification, instead of building a hypothesis from the corpus.

Corpus analysis has a wide variety of research focus, from world Englishes (Hundt, 2015), literary style and literary texts (Mahlberg, 2015) to translation (Bernardini, 2015) and lexicography (Paquot, 2015). However, a major contribution of corpus linguistics has been to English Language Teaching. In countries where English is neither an official language, nor spoken among minorities in that country, in other words where English is learned as a foreign language but not as a second language, using corpusbased materials gains more importance as learners in such countries have limited access to the target language. Using corpus-based materials enable learners to produce target language items at a higher rate and sound more natural in the target language.

According to Pawley and Syder (1983), people tend to acquire and use chunks in a language. For instance, instead of asking the question "what is the current level of your well-being?", people simply ask the question "how are you?"; and they ask "will you marry me?" instead of "do you have the intention of marrying me?" even though the sentences have similar meanings (Pawley \& Syder, 1983). In order to be fluent and save time, learners retrieve these chunks instead of creating novel sentences that have the same meaning. These chunks, memorized as wholes and retrieved as one item from longterm memory are called FSs (Wood, 2006).

FS was defined as "a sequence, continuous or discontinuous, of words or other meaning elements, which is, or appears to be, prefabricated: that is stored and retrieved whole from the memory at the time of use, rather than being subject to generation or analysis by the language grammar" (Wray 2000, p. 465) have also been referred to as lexical bundles (Biber et al., 1999), chunks, preassembled speech, and frozen phrases (Wray, 2002, p. 465). Over the years, scholars have not been able to agree on a universal definition for FSs due to their length and variety in forms. A FS can be as long as "you can lead a horse to water, but you cannot make him drink" or as short as "oh, no!" (Schmitt \& Carter, 2004). It can be a sentence such as "I don't understand" or a conjunction such as "first of all". So it can be concluded that FSs can come in different shapes and lengths, which makes it difficult to propose a comprehensive definition and this is one of the biggest problems in this research area (Schmitt \& Carter, 2004).

Instead of coming up with a unified definition, researchers came up with some criteria to identify FSs. For instance, Schmitt and Carter (2004) divided their criteria into two disciplines, psycholinguistics and corpus linguistics. In psycholinguistics, a string of words becomes a FS if individuals know it and store it in their vocabulary as a whole. To test the first criterion, whether individuals know the string of words in question, scholars examine whether these individuals produce the string of words more than once. To test the second criterion, whether individuals store the string of words as a whole, scholars look at the intonation of the string of words. They explore whether individuals pronounce the string as a whole, completely or they give pauses in between.

Another possible criterion for FSs has been their frequency in corpora. Scholars have tried to determine a pre-set level of frequency for a string of words. The cut-off frequency levels have been 40 occurrences per million words (Biber, Conrad, \& Cortes, 2004). Recently, it has been decreased to 10 occurrences per million words (Bardovi-Harlig, Mossman, \& Vellenga, 2015). However, these levels are arbitrary (Wray, 2002) because a phrase, which has already been accepted as a FS (e.g., To top it off) may have a low frequency in the corpus (Adolphs \& Durow, 2004). 


\subsubsection{Formulaic sequences (FS)}

According to Martinez and Schmitt (2012), formulaic language makes up more than half of both English spoken (58.6\%) and written (52.3\%) discourse (Erman \& Warren, 2000, as cited in Martinez \& Schmitt, 2012). Given this fact, the knowledge and use of formulaic language have many advantages for non-native speakers. For example, the knowledge of FSs gives confidence to nonnative speakers to use them in genuine interaction with native speakers (Wray 2002). Moreover, the use of FSs makes it easier for non-native speakers to be understood by native speakers. Formulaic language has advantages in processing because they are mostly fixed and perceived as one single item, so it saves time to use a FS because less energy is spent on creating a novel expression. Therefore, the processing both for the speaker and the hearer becomes easier. In addition, the use of FSs enables a non-native speaker to sound native-like in both spoken and written discourse (Boers, Eyckmans, Kappel, Stengers, \& Demecheleer, 2006; Bybee, 2002; Olhrogge, 2009; Skehan, 1998).

Although the importance of FSs have been recognized by many scholars (e.g., Chen \& Baker, 2010; Conklin \& Schmitt, 2008; Wei \& Ying, 2011), there are relatively few studies that involved FSs, especially in contexts where English is taught as a foreign language (Gomez-Burgos, 2015) and fewer experimental studies that enabled learners to acquire FSs. For example, in Jones and Haywood (2004), participants were divided into experimental and control groups. In the experimental group, the participants' attention was drawn to FSs in writing tasks with the help of concordance lines. After the 10-week treatment, the experimental group was more aware of the FSs than the control group. Cortes (2006) found a similar result in her study. She conducted pre- and post-tests in a writing-intensive history class and found no significant differences between the experimental and control groups in terms of the FSs taught; however, the participants in the experimental group were more aware of the FSs. Similar results were also obtained by Anğ (2006) who examined the effects of concordancing on the acquisition of FSs in an experimental study in Turkey.

Müjdeci (2014) investigated the effect of instruction on receptive and productive knowledge of FSs. The author found a significant difference between the experimental and control groups with respect to receptive and productive knowledge of FSs in that the difference between receptive and productive knowledge of FSs was smaller for the participants in the experimental group than those in the control group, which implies that the instruction on FSs might have helped the learners in the experimental group close the gap between the receptive and productive knowledge of FSs.

In an attempt to increase students' awareness about collocations through text chunking, Boers et al. (2006) asked students to highlight what they believed were collocations. Students in the experimental group were engaged in text chunking whereas the control group was engaged in other activities. As a post-test, the students were asked to retell a text in their own words. The results showed that the students in the experimental group used significantly more FSs than the control group. Schmitt, Dörnyei, Adolphs and Durow (2004) investigated the effects of learner differences such as age, gender, aptitude and motivation on the retaining of the targeted FSs. The authors found that although the participants in the study improved both their comprehension and perception of the FSs, the variables did not correlate with the uptake of FSs. The authors could not reach a conclusion regarding whether the uptake stemmed from the instruction in the study or being in an ESL context where the participants were immensely exposed to the target language.

To sum up, there are not many interventional studies on FSs conducted either abroad or in Turkey. In Turkey, four of the studies (Anğ, 2006; Gürsoy, 2008; Kız1, 2009; Müjdeci, 2014) included an instruction on FSs, while few (Aksar 2010; Koban Koç \& Koç 2017) depict FSs found in TV shows. In addition, to the best knowledge of the researcher, there is not a study that includes corpus-based teaching, FSs and pragmatic competence under the same study and that tests both comprehension and 
the production layers of pragmatic competence, both in the short (immediately after the treatment) and long (two weeks after the treatment) term.

\subsection{Research questions}

The present study aims to fill this gap by demonstrating the effects of, if any, corpus-based teaching on the comprehension and production of 19 FSs in pragmatically appropriate contexts in a quasiexperimental design with one experimental and one control group. The study aims to answer the following research questions:

1. What is the short- and long-term effect of corpus-based teaching of 19 FSs on pragmatic comprehension and production of learners of English as a foreign language?

a. Does corpus-based teaching cause significant changes in the comprehension and production of the target FSs in the short term (right after the treatment)?

b. Does corpus-based teaching cause significant changes in the comprehension and production of the target FSs in the long term (two weeks after the treatment)?

\section{Method}

\subsection{Sample / Participants}

A total of 35 participants were divided into experimental $(\mathrm{N}=19)$ and control groups $(\mathrm{N}=16)$. The participants were first-year students enrolled in the English Language Teaching program of a government university. The data were collected in the Fall Term of the 2018-2019 academic year. The students represented one native language background: Turkish. The statistical analysis from the pre-test scores from both groups revealed that there were no statistical significant differences between the two groups in terms of knowledge of the target items.

\subsection{Instrument( $(s)$}

The corpus used in the current study is the Corpus of Contemporary American English (COCA; Davies, 2008; https://corpus.byu.edu). The reason why COCA was selected for this study is that it is the largest freely-available online corpus of English. After choosing the lower cut-off limit for an expression to be considered frequent, which is 10 occurrences/million words, according to the guidelines proposed by Bardovi-Harlig et al. (2015) and Biber et. al. (1999), the frequently used FSs formed the ultimate list of the target items in the current study, shown in Table 1. The number of occurrences per million words for each FS can also be seen in the Table. The frequency for the FS I agree but is the only one not given because it is impossible to know what may come in between I agree and but as I agree but is not always used as a fixed chunk.

Table 1. FSs and their frequencies in the COCA corpus

\begin{tabular}{llll}
\hline Agreements & Disagreements & Self-clarifications & Other-clarifications \\
That's right: 143 & Yeah but: 22 & What I mean: 18 & Do you mean: 22 \\
You're right: 30 & That's not true: 11 & In other words: 45 & What do you mean: 19 \\
That's true: 39 & I don't think so: 24 & I mean: 1053 & Are you saying: 14 \\
I agree: 67 & I disagree: 14 & & You're saying: 42 \\
Good point: 15 & Yes but: 21 & & What you're saying: 14 \\
& I agree but & & \\
\hline
\end{tabular}




\subsection{Data collection procedures}

Two weeks after the pre-test, the experimental group received an instruction, which was composed of three activities, one for recognition and two for production of the targeted items. The activities were adapted from the activities in Bardovi et al. (2015) and were conducted only once. For the first activity, the participants read a total of 19 dialogues, taken from COCA, which included the target FSs in them. The participants were asked to underline the parts which helped them understand if Person B agrees or disagrees with Person A and the parts which showed clarification done by either Person A or B. The parts in the dialogues that they were asked to find were the targeted FSs. After 20 minutes, the participants discussed the answers with the instructor. The instructor showed on the board the list of the FSs in the study and only told the participants that there were alternatives to the FSs and gave no further linguistic information, as the point in the current study is corpus-based teaching, not explicit teaching.

For the second activity, the participants were divided into pairs. Each pair received a paper on which there were five statements and guidelines that showed who agreed and disagreed with each statement. The pairs were asked to compose spoken dialogues according to the guidelines provided on the paper. They were allowed to look at the board to use a variety of FSs. This activity lasted for 20 minutes. For the last activity, the participants formed groups of three. One person became a judge who decided whether or not the other two participants used different FSs in the discussions. After discussing five statements, the participants changed roles. The activity continued until every participant in each group became a judge. There were 15 statements in total to be discussed. After these three activities, the immediate post-test for the experimental group was conducted.

Since the study looks into both short term and long-term gains, if any, it employs a pre-test, immediate post-test and delayed post-test design with one hour of instruction of the target items in the experimental group only. Before the actual data collection, the data collection tools were piloted to a different group of students in the same department and necessary changes were made in the materials. The actual data collection process lasted for 5 weeks. The pre-test was conducted to the experimental group on week 1 . On week 2, the control group received their pre-test. On week 3 , the experimental group received the instruction and the immediate post-test right after the instruction. On week 4, the control group received their post-test and finally on week 5, the experimental group received their delayed post-test. Thus, each group received the tests with two weeks interval.

\subsection{Data analysis}

The data received from the MCDTs were analyzed quantitatively using the Statistical Program for the Social Sciences (SPSS).

\section{Results}

Table 2 shows the descriptive statistics for the pre-test MCDT for the experimental and control groups.

Table 2. Descriptive statistics for the MCDTs

\begin{tabular}{cllll}
\hline Groups & $\mathrm{N}$ & Mean & SD & SE \\
\hline Experimental & 19 & 13.47 & 1.429 & .328 \\
Control & 16 & 13.69 & 1.195 & .299 \\
\hline
\end{tabular}


According to the Table, the mean scores are alike for the experimental and the control group. To understand if these mean scores were statistically significant from each other or not, the test of homogeneity of variances, also known as Levene's test, was conducted. The groups did not differ significantly from each other in terms of their pre-test MCDT scores. Then a normality test for all MCDTs in the study, namely the pre-test, immediate post-test and delayed post-test MCDTs, was run to decide if the data distribution is normal or not. The results showed that all MCDT scores, pre-test, immediate post-test and delayed post-test MCDTs, violated the assumption of normality as the p values were lower than .05 ( $p=0.11$ for pre-test, $\mathrm{p}=.004$ for immediate post-test and $p=0.49$ for delayed post-test). Therefore, the non-parametric test Wilcoxon Signed Rank Test, which is designed for repeated (more than one) measures (Pallant, 2011), was employed for the analyses. Since Wilcoxon Signed Rank Test allows one to conduct only two repeated measures, but there were three occasions in the present study (pre-test, immediate post-test and delayed post-test), the test was conducted combining these three occasions. The Wilcoxon Signed Rank Test did not reveal any statistically significant differences between pre-test and immediate post-test; between immediate post-test and delayed posttest and finally between pre-test and delayed post-test.

The ODCTs formed the qualitative part of the present study. To analyze the results of ODCTs, a holistic rubric was designed by the researcher under one criterion, using a variety of the targeted FSs in speech, with possible grades of one, two or three. Although there were six statements in the ODCT for agreements, disagreements and other-clarifications; two elaboration questions were added to assess selfclarification FSs, which made eight possible different FSs. Taking the maximum number as eight, the researcher designed the rubric as below.

Table 3. The holistic rubric designed for the analyses of the ODCTs

Criterion
$\begin{aligned} & \text { The participant uses a variety of } \\ & \text { formulaic sequences } \\ & \text { speeches. }\end{aligned}$

Table 4 below shows the descriptive statistics for the pre-test and immediate post-test ODCTs for both experimental and control groups.

Table 4. Descriptive Statistics for pre-test and immediate post-test ODCTs

\begin{tabular}{|c|c|c|c|c|}
\hline Groups & & $\mathrm{N}$ & $\mathrm{M}$ & SD \\
\hline \multirow[t]{4}{*}{ Experimental } & Pre-test & 1 & 1.5 & .61 \\
\hline & & 9 & 3 & 2 \\
\hline & Immediate Post-test & 1 & 2.7 & .56 \\
\hline & & 9 & 4 & 2 \\
\hline \multirow[t]{4}{*}{ Control } & Pre-test & 1 & 1.3 & .61 \\
\hline & & 6 & 8 & 9 \\
\hline & Immediate Post-test & 1 & 1.3 & .61 \\
\hline & & 6 & 8 & 9 \\
\hline
\end{tabular}


The results showed that the mean scores of the experimental group increased across the two tests whereas the mean scores of the control group stayed exactly the same. To decide whether a parametric or non-parametric test was needed for further analyses, normality tests were run for all ODCTs.

Table 5. Normality Tests for All ODCTs

\section{Tests of Normality}

\begin{tabular}{|c|c|c|c|c|c|c|}
\hline & \multicolumn{3}{|c|}{ Kolmogorov-Smirnov ${ }^{\mathrm{a}}$} & \multicolumn{3}{|c|}{ Shapiro-Wilk } \\
\hline Pre-test & $\begin{array}{l}\text { Statistic } \\
.332\end{array}$ & $\begin{array}{l}\text { df } \\
19\end{array}$ & $\begin{array}{l}\text { Sig. } \\
.000\end{array}$ & $\begin{array}{l}\text { Statistic } \\
.733\end{array}$ & $\begin{array}{l}\mathrm{df} \\
19\end{array}$ & $\begin{array}{l}\text { Sig. } \\
.000\end{array}$ \\
\hline Immediate Post-test & .470 & 19 & .000 & .536 & 19 & .000 \\
\hline Delayed Post-test & .211 & 19 & .026 & .815 & 19 & .002 \\
\hline
\end{tabular}

Like the MCDT data, the ODCT data did not distribute normally either, as can be seen from the Table $(\mathrm{p}<.05)$. Therefore, Wilcoxon Signed Rank Test was run to see differences between pre-test and immediate post-test; immediate post-test and delayed post-test and finally between pre-test and delayed post-test.

Table 6. Wilcoxon Signed Rank Test Results for Pre-test and Immediate Post-test ODCTs

\begin{tabular}{lll}
\hline Experimental & Total N & 19 \\
Test Statistic & 136.000 \\
Standard Error & 18.762 \\
Standardized Test Statistic & 3.624 \\
Asymptotic Sig. (2-sided test) & .000 \\
\hline Control & Total N & 16 \\
& Test Statistic & 14.000 \\
Standard Error & 5.534 \\
& Standardized Test Statistic & .000 \\
& Asymptotic Sig. (2-sided test) & 1.000 \\
\hline
\end{tabular}

The results showed that there was a significant change between the pre-test and immediate post-test $(p=.001)$. To evaluate the degree of significance, i.e. effect size, Cohen's d was calculated for the experimental group and the result was very large effect $(r>0.5, r=1.99)$. This shows that the treatment sessions were effective in the short term and the participants were able to integrate the targeted FSs into their speeches right after the treatments. Another interesting finding was that the pre-test and immediate post-test $(p=1.00)$ results were the same for the control group. These results clearly showed that the treatment sessions have had a positive effect on the participants' productions of the targeted FSs. Now the question to be answered is whether the participants maintained their performance over the delayed post-test, which was two weeks after the immediate post-test. 
Table 7. Wilcoxon Signed Rank test results for immediate and delayed post-test ODCTs

\begin{tabular}{llllll}
\hline \multicolumn{7}{c}{ Descriptive Statistics } \\
\hline Immediate Post-test & $N$ & Minimum & Maximum & Mean & $S D$ \\
Delayed Post-test & 19 & 1 & 3 & 2.74 & .562 \\
\hline
\end{tabular}

Related-Samples Wilcoxon Signed Rank Test summary

\begin{tabular}{ll}
\hline Total N & 19 \\
\hline Test Statistic & 18.000 \\
Standard Error & 16.771 \\
StandardizedTest Statistic & -2.504 \\
AsymptoticSig. (2-sided test) & .012 \\
\hline
\end{tabular}

The Table showed that the mean score of the experimental group in immediate post-test dropped from 2.74 to 2.05 in delayed post-test and this drop was statistically significant $(\mathrm{p}=.012)$. The final question to be answered here is whether there was a statistically significance between the pre-test and delayed post-test ODCTs.

Table 8. Descriptive Statistics and Wilcoxon Signed Rank Test Results for pre-test and delayed post-test ODCTs

\begin{tabular}{llllll}
\hline \multicolumn{5}{c}{ Descriptive Statistics } \\
Pre-test & $N$ & Minimum & Maximum & $M$ & $S D$ \\
Delayed Post-test & 35 & 1 & 3 & 1.46 & .611 \\
& 19 & 1 & 3 & 2.05 & .780 \\
\hline
\end{tabular}

Related-Samples Wilcoxon Signed Rank Test summary

\begin{tabular}{ll}
\hline Total N & 19 \\
\hline Test Statistic & 57.000 \\
Standard Error & 10.747 \\
StandardizedTest Statistic & 2.233 \\
Asymptotic Sig. (2-sided test) & .026
\end{tabular}

It can be seen that the mean score of the experimental group in pre-test was 1.46 , whereas it was 2.05 in delayed post-test, which showed an increase. To understand if this increase was statistically significant or not, Wilcoxon Signed Rank Test was run and the test showed that the increase was actually significant as the $\mathrm{p}$ value is less than $.05(\mathrm{p}=0.026)$. 


\section{Discussion}

The present study aimed to find out if corpus-based teaching had an effect on pragmatic comprehension and production of 19 FSs by the learners of English as a foreign language. The results regarding the MCDTs showed that neither the experimental nor the control group significantly improved or worsened their pre-test performances over immediate or delayed post-test. This finding is similar to Taguchi's (2008) study in which he found that although the speed of comprehension increased over tests, accuracy did not. Felix-Brasfeder and Hasler-Baker (2015) also found minor pragmatic competence gains across pre-test and post-test, which could not reach the significance threshold. To the best knowledge of the researcher, the current study is the first one, which found that the MCDT scores of participants decreased over time, though not significantly, even after the treatment. As stated before, no significant changes were expected because the starting point of the participants was already high, but its decrease right after the treatment was not expected. One reason for this decrease may be that the treatment sessions included one recognition and two production activities, putting more emphasis on the production rather than the comprehension; as production was assumed to take more time and effort than the comprehension. Another reason might be that the treatment sessions did not include explicit teaching, which shows the possible grammatical forms the FSs could be in and used. Without explicit teaching, the participants may have had difficulties in remembering the forms and usages of the FSs.

The MCDT performance of the control group was worse than that of the experimental group, showing that the treatment slowed down the unlearning of the FSs, though it did not stop it altogether. For both groups, this loss could be explained by the lack of explicit instruction on the FSs and the fact that participants already scored high on the MCDT in the pre-test and thus may not have seen the necessity to improve themselves.

Regarding the ODCTs, the results showed that although the control group did not improve significantly, the experimental group improved their performance especially in the immediate post-test, with a very large effect (Cohen's d). Although this performance did not improve as much in the delayed post-test, there was still a statistically significant gain in nine FSs out of 19 for the experimental group between the pre-test and delayed post-test. Another interesting finding was that although the participants saw the same FSs both in the MCDT and in the treatment session, the experimental group never produced the following five formulaic sequences: good point, I agree but, in other words, are you saying and you're saying probably because they have not learned how to mitigate their disagreements by using an agreement token (i.e. I agree but), and they avoided paraphrasing or repeating what the interlocutor has said by opting for what do you mean instead of are you saying or you're saying. However, for an improved pragmatic competence, they should be able to show their attention by showing they understood at least a bit of what is being talked about. Overall, the study showed that the treatment session worked well for the production but not for the comprehension of the targeted 19 FSs.

\section{Conclusions}

The present study showed the importance of recycling and repetition of the target learning items on a regular basis. The fact that the MCDT performances worsened over time (though not significantly) meant that learners may rely on their success when they score high on a test, but if they do not practice or get an instruction about it, they tend to worsen their performances. This is also valid for production, because there was a decline from the immediate post-test to the delayed post-test, although there was a significant gain overall (between the pre-test and delayed post-test ODCTs for the experimental group). 
So, teachers of English should not take it for granted that their students have learned a language item, no matter how easy it is, and they should have their students always review what they have learned.

Corpus-based teaching, in this sense, could be helpful for both teachers and learners of English because it provides the language which is actually being used by native speakers of English, rather than the English language in the course books. When students are exposed to rich corpus data, they will widen their horizons about language, know that language is not black or white and vary their language use in order to be pragmatically more competent. When combined with speaking activities, which involve active learner participation like in the present study, corpus-based teaching can yield longlasting learning.

This study investigated how to increase pragmatic competence through a non-traditional way. Further studies may focus on how participants perform politeness in conversations because there were incidents in the present study where the participants directly replied with "What?" One of the participants checked if the interviewer understood him/her by asking "Do you understand?" instead of "Am I clear?" or "Is it clearer now?" Therefore, politeness and addressing issues could be saught in a further study. Moreover, many participants in the study formed very long sentences for a conversation in the 'otherclarification' part. Further studies could focus on how to help learners form more native-like and shorter sentences. Finally, as the control group was not exposed to a treatment at all, further studies may include other types of teaching (e.g., implicit or explicit teaching, computer-assisted language teaching) in their studies and compare it to corpus-based teaching.

\section{Ethics Committee Approval}

The authors confirm that ethical approval was obtained for this study (Approval Reference Number: 35853172-755.02.06)

\section{References}

Aarts, J. (1991). Intitution-based and observation-based grammars", in Aijmer et al. (Eds.), English Corpus Linguistics (pp. 44-62). London: Longman.

Aksar, M. (2010). Formulaic sequences in English TV series. Unpublished M.A. thesis, Uludağ University.

Anğ, F. (2006). Effectiveness of corpus consultation through concordancing on the formulaic academic language use of freshman ELT students. Unpublished M.A thesis, Boğaziçi University.

Bardovi-Harlig, K., Mossman, S., \& Vellenga, H. E. (2015). Developing corpus-based materials to teach pragmatic routines. TESOL Journal, 6(3), 499-526.

Biber, D., Johansson, S., Leech, G., Conrad, S., \& Finegan, E. (1999). Longman grammar of spoken and written English. London, UK: Longman.

Boers, F., Eyckmans, J., Kappel, H., Stengers, H., \& Demecheleer, M. (2006). "Formulaic sequences and perceived oral proficiency: putting a Lexical Approach to the test", Language Teaching Research, (10)3, 245-261.

Chen, Y., \& Baker, P. (2010). Lexical bundles in L1 and L2 academic writing. Language Learning \& Technology, 14(2), 30-49. 
Cheng, H., \& Dörnyei, Z. (2007). "The use of motivational strategies in language instruction: the case of EFL teaching in Taiwan", Innovation in Language Learning and Teaching, 1(1), 153-174.

Conklin, K., \& Schmitt, N. (2008). "Formulaic sequences: Are they processed more quickly than nonformulaic language by native and nonnative speakers?", Applied Linguistics, 29(1), 72-89. http://dx.doi.org/10.1093/ applin/amm022.

Dörnyei, Z. (1998). "Motivational factors in the second language attainment: A review of research in Hungary", Acta Linguistica Hungraia. 44, 261-275.

Erman, B., \& Warren, B. (2000). "The idiom principle and the open choice principle", Text, 20(1), 2962.

Félix-Brasdefer, J. C., \& Hasler-Barker, M. (2015). "Complimenting in Spanish in a short-term study abroad context", System, 48, 75-85.

Fox, G. (1998). "Using corpus data in the classroom", in B. Tomlinson (Ed.), Materials development in language teaching (pp. 25-43). Cambridge: Cambridge University Press.

Gürsoy, E. (2008). The noticing of formulaic sequences by Turkish learners of English. Unpublished M.A. thesis, Çukurova University.

Horwitz, E. K., M. Tallon \& H. Luo (2009). "Foreign language anxiety”, in J. C. Cassady (ed.), Anxiety in schools: The causes, consequences, and solutions for academic anxieties. New York: Peter Lang.

Jones, M., \& Haywood, S. (2004). "Facilitating the acquisition of formulaic sequences: An exploratory study", in N. Schmitt (Ed.), Formulaic sequences (pp. 269-300). Amsterdam, the Netherlands: John Benjamins.

Gómez-Burgos, E. (2015). "First year university students' use of formulaic sequences in oral and written descriptions", PROFILE Issues in Teachers' Professional Development, 17(1), 25-33. http://dx.doi.org/10.15446/profile.v17n1.43438.

Kasper, G., \& Rose, K. (2002). "Pragmatic development in a second language". Malden, MA: Blackwell.

Kız1, J. A. (2009). The role of formulaic sequences in speaking fluency in intermediate English as a foreign language classes. Unpublished M.A thesis, Gazi University.

Kilgarriff, A. (2014). "Corpora in English language teaching". Retrieved from https://www.britishcouncil.org/voices-magazine/corpora-english-language-teaching on January 11, 2018.

Koban-Koç, D. \& Koç, S. E. (2017). "On the Role of Media Input in the Learning of Formulaic Sequences by

EFL Learners".TESL Canada Journal (Special Issue), 34(3), 93-110.

http://dx.doi.org/10.18806/tesl.v34i3.1275.

Leech, G.(1983). Principles of pragmatics. Longman: London/New York.

Leech, G. (1991). "The state of the art in corpus linguistics", in Aijmer K. and Altenberg B. (eds.) English Corpus Linguistics: Studies in Honour of Jan Svartvik, pp 8-29. London: Longman.

MacIntyre, P. D. (2007). "Willingness to communicate in the second language: understanding the decision to speak as a volitional process", The Modern Language Journal, 91, 564-576.

Martinez, R., \& Schmitt, N. (2012). “A phrasal expression list”, Applied Linguistics, 33(3), 299-320.

McDonough, S. (2007). “Motivation in ELT”. ELT Journal, 61(4), 369-371. 
McEnery, T.; Xiao, R., \&Tono, Y. (2006). Corpus-Based Language Studies. An Advanced Resource Book (Routledge Applied Linguistics). London, New York: Routledge.

Müjdeci, Ş. (2014). The effects of focused instruction on the receptive and productive knowledge of formulaic sequences. Unpublished M.A. thesis, Gazi University.

Ohlrogge, A. (2009). "Formulaic expressions in intermediate EFL writing assessment", in R. Corrigan, E. A. Moravcsik, H. Ouali, and K. M. Wheatley (Eds.). Formulaic Language Volume 2: Acquisition, Loss, Psychological Reality, and Functional Explanations. John Benjamins Publishing Company, pp. 375-86.

Oxford, R. L., \& Shearin, J. (1996). "Language learning motivation in a new key”, in Pawley, A., \& Syder, F.H. (1983). Two puzzles for linguistic theory: Nativelike selection and nativelike fluency. In J.C. Richards \& R.W. Schmidt (Eds.), Language and communication (pp. 191-226). New York: Longman.

Pemberton, C. (2018). Analysis and Evaluation of Three ESL Coursebooks. Unpublished master's thesis. University of Birmingham, UK.

Richards, J. C. (2001). Curriculum development in language teaching. New York: Cambridge University Press.

Robinson, P., \& Ellis, N. C. (2008). "An introduction to cognitive linguistics, second language acquisition, and language instruction”, in P. Robinson, \& N. C. Ellis (Eds.). Handbook of cognitive linguistics and second language acquisition. New York: Routledge.

Schmitt, N., \& Carter, R. (2004). "Formulaic sequences in action", in N. Schmitt, \& Ronald C. (Eds.), Formulaic Sequences: Acquisition, Processing, and Use. John Benjamins Publishing.

Schmitt, N., Dörnyei, Z., Adolphs, S., and Durow, V. (2004). "Knowledge and acquisition of formulaic sequences: A longitudinal study", in N. Schmitt (Ed.), Formulaic Sequences Acquisition, Processing and Use (pp. 55-86). Amsterdam: Benjamins.

Sinclair, J. (1991). Corpus Collocation Concordance. Oxford: Oxford University Press.

Sinclair, J. (2004). How to use corpora in language teaching. Amsterdam: John Benjamins Publishing Company.

Skehan, P. (1998). A cognitive approach to language teaching. Oxford, UK: Oxford University Press.

Stipek, D.J. (2002). Motivation to learn: Integrating theory and practice (4th ed.). Boston, MA: Allyn and Bacon.

Teubert, W. (2005). "My version of corpus linguistics". International Journal of Corpus Linguistics, $10(1), 1-13$.

Tognini-Bonelli, E. (2001). Corpus Linguistics at Work. Amsterdam: John Benjamins Publishing Company.

Wei, L., \& Ying, H. (2011). “On the role of formulaic sequences in second language acquisition”, USChina Foreign Language, 9(11), 708-713.

Wenden, A. (1998). Learner Strategies for Learner Autonomy. Great Britain: Prentice Hall.

Wood, D. (2006). "Uses and Functions of Formulaic Sequences in Second Language Speech: An Exploration of the Foundations of Fluency". Canadian Modern Language Review, 63(1), 13-33. 
Wray, A. (2000). "Formulaic sequences in second language teaching: Principle and practice". Applied Linguistics, 21, 463-489.

Appendix A. Multiple Choice Discourse Completion Test (MCDT) sample questions

1.Which one is the most appropriate for the blanks below?
a) Good point
b) I agree
c) That's right

David: Is that for you or him?

Greenlee: No, Ryan and on this, and I'm sure.

Appendix B. Oral Discourse Completion Test (OCDT) sample questions

1. You have the same opinion with this statement. After I say my opinion, you continue the dialogue.: "It is better to use printed books or articles to study than using the internet." Yes, it's because the Internet can distract you and you may stop studying.

Appendix C. The first activity in the treatment

Read the dialogues below. How do you understand that (person) B has the same opinion with (person) A / has a different opinion from A / does not understand person A / is not understood by A? In some dialogues, $\mathrm{A}$ has the same opinion with (person) $\mathrm{B} /$ has a different opinion from $\mathrm{B} /$ does not understand person B / is not understood by B.

Example:sep Mitt Romney is running for presidency in the USA in 2011. He is live on a show on TV one night. Next day, two people are talking about him and that night.

Person A: I agree with you, Romney had a good night.s. Person B: OK but I didn't say Romney had a good night. I just said he looked presidential, so does Martin Sheen. Do we want him to run the country?

Appendix D. The second activity in the treatment

\begin{tabular}{|c|c|}
\hline Student A & Student B \\
\hline $\begin{array}{l}\text { "Fast food restaurants are beneficial to } \\
\text { society." First, read this statement to your } \\
\text { partner. Then, say that you have the same } \\
\text { opinion with this statement by giving } \\
\text { explanations and examples. }\end{array}$ & $\begin{array}{l}\text { Your partner will read and agree with the } \\
\text { statement "Fast food restaurants are beneficial } \\
\text { to society." However, you do not understand } \\
\text { what s/he is saying. Ask for clarification.s[ep. }\end{array}$ \\
\hline
\end{tabular}

Appendix E. The third activity in the treatment

You will be in groups of three. One will be judge, the other two will speak. The judge will decide if the speakers use different formulaic sequences in each conversation and if they use them correctly. After 5 dialogues, you will change the roles, until all of you become a judge. There will be 15 dialogues in total.

\section{Sample Statements:}

1. Higher education should be available only to good students. 
2. Children should begin their formal education at a very early age. 3. Friends are the most important influence on young adults.

4. People behave differently when they wear different clothes.

5. The decisions that people make quickly are always wrong.

\title{
Change roles!
}

6. People are never satisfied with what they have; they always want something more.

\section{Edimsel anlama ve konusmanin geliştirilmesi: Yabancı dil olarak Ingilizce ortamında kalıplaşmış dil sözcüklerinin derleme dayalı ogretimi}

\begin{abstract}
$\ddot{O} \mathbf{z}$
$\mathrm{Bu}$ çalışma, derleme dayalı ögretimin uzlaşma, uzlaşamama, kendini açıklama ve diğer açıklamalar olarak kategorize edilmiş 19 kalıplaşmiş dil sözcüklerinin Ingilizceyi yabancı dil olarak öğrenen öğrencilerin edimsel olarak anlaması ve konuşmasına olan etkisini araştırmayı hedeflemektedir. Çalışmanın yarı-deneysel bir deseni olup ön-test, son-test ve geciktirilmiş son-testten oluşmaktadır. Çalışmaya 35 öğrenci katılmış ve iki gruba ayrılmışlardır. Deneysel grup (N=19) derleme dayalı Ingilizce öğretimine maruz kalmı, kontrol grubu ise geleneksel öğretime (N=16) maruz kalmıştır. Sonuçlar, deneysel grubun kalıplaşmış dil sözcüklerini kullanması açısından ön-test ve son-test; son-test ile geciktirilmis son-test arasında istatistiksel olarak önemli farklılıkların olduğunu göstermiştir. Sonuçlar derleme dayalı öğretimin bir dili konuşmadaki etkisini ve öğrencilerin edimsel yeterliklerini geliştirmesi icin dili doğal olarak öğrenmelerinin gerekliligini göstermiştir.
\end{abstract}

Anahtar sözcükler: Yabancı dil olarak Ingilizcenin öğretimi; yeterlik; anlama; konuşma; derlem, kalıplaşmış dil sözcükleri

\section{AUTHOR BIODATA}

Dr. Nihan Yilmaz received her Ph.D. degree in English Language Teaching from Hacettepe University, Turkey. She worked as an English language instructor at the Preparatory School of Foreign Languages at Hacettepe University. Her areas of interests are discourse analysis and teacher training.

Dr. Koban Koç is currently working as an Associate Professor in the Faculty of Education/Department of Foreign Languages Education at İzmir Democracy University, İzmir, Turkey. She received a Ph.D. degree in Linguistics from the City University of New York, USA, an M.A. degree in Teaching English as a Second Language (TESOL) from New York University, USA, and a B.A. degree in Teaching English as a Foreign Language (EFL) from Middle East Technical University, Turkey. She taught in a variety of institutions such as the City University of New York, Pace University, the College of New Rochelle in the United States and Hacettepe University in Turkey. Her current interests include sociolinguistics, bilingualism/multilingualism and teacher education. 